\title{
Neuraminidase の動物輸注実験
}

\author{
—neuraminidase と炎症の関連——
}

\section{目黒 嵩・山田兼雄 ${ }^{*}$, 稲垣 稔**}

\begin{abstract}
Infusion study of neuraminidase in rabbit—role of neuraminidase on inflamation

Takashi Meguro • Kaneo Yamada*, Minoru Inagaki**
\end{abstract}

生体に扔いて外因性, 内因性いずれかの原因で neuraminidase 活性が上昇すれば生体の糖蛋白, 糖ペプチ ド，糖脂質が脱シアル化して，これらの種々の生物活性 に重大な影響を与えることが考えられる. 感染, 炎症に より neuraminidaseの関与は過去より考えられ, Fischer ら は肺炎に执いて neuraminidase 活性上昇による thomeen cryptantigen の出現を示した。 また, その他 の $2 \sim 3$ の報告 ${ }^{2}$ もあるが, 近年筆者ら ${ }^{3)}$ は川崎病で初期 に血中 neuraminidase 活性が著明に上昇していることを 示した。

今回，筆者らは炎症に打恀る neuraminidase の上昇, またこの結果における脱シアル化の変動について検討を 行ら手がかりとして, neuraminidase の動物への投与実 験を行い, 種々の炎症反応に現れる諸種の因子の変化を 検討したので報告する。

\section{方 法}

\section{(1) 輸注方法}

$2.5 \sim 3.5 \mathrm{~kg}$ の家鬼に Cl. perfergens の neuraminidase (シグマ社, type V, VI)を Solita T 3 (シミズ薬品) に $5 \sim 7 \mathrm{u} / 120 \mathrm{~m} l$ に溶解して, 無菌的に注入した.

(i)one shot 注入法: $0.01 \sim 1.0 \mathrm{u} / \mathrm{ml} / \mathrm{kg}$ の範囲の neuraminidase を耳静脈より one shot で注入した。

(ii)持続注入法: $2 \mathrm{u} / \mathrm{kg} / 24 \mathrm{hr}$ の neuraminidase を infusion sump を用いて $5 \mathrm{ml} / \mathrm{hr}$ の流速で耳静脈より, カテラン針 $(23 \mathrm{G})$ で持続注入した.

(2) 採血方法

neuraminidase の注入部位と反対側の耳静脈より，21 Gの翼付針を用いて血清, クェン酸加血漿, EDTA 血 を neuraminidase 輸注前, および輸注後 2 週間まで採 血 ( 1 回 $5 \mathrm{ml}$ ) した.

(i血清：抗凝固剂なしで全血 $1.5 \mathrm{~m} l$ 採血し, 約30分

* Department of Pediatrics, St. Marianna University, School of Medicime 聖マリアンナ医科大学 小览科学教室

** Department of Pediatrics, Keio University 慶応 義塾大学医学部小児科学教室
放置後 $3,000 \mathrm{rpm}, 10$ 分間遠心分離して血清を得た。こ の血清は総蛋白, 蛋白分画測定に用いられた.

(ii) クエン酸加血漿： $3.8 \%$ クエン酸ナトリウム $1 / 10$ 容 加血液 $2.5 \mathrm{ml}$ 採血 $し, 3,000 \mathrm{rpm}, 4^{\circ} \mathrm{C}, 10$ 分間遠心 分離して血漿を得た。この血漿は凝固時間, フィブリ, ーゲン, 遊離シアル酸, オルソムコイドの測定に用いら れた。

(iii)EDTA 血: EDTA $2 \mathrm{Na}$ 加血液 $(1 \mathrm{mg} / \mathrm{ml}) 1.0 \mathrm{~m} l$ 採血した. これは血小板数, 白血球数, 赤血球数, $\mathrm{Ht}$, 血小板中シアル酸の測定に用いられた。

\section{(3) 測定方法}

(i) 血中 neuraminidase の测定 ${ }^{4)}$ : 螢光合成基質法を用い た.クエン酸加血漿 $20 \mu l$ と $60 \mu \mathrm{M} \mathrm{N}$-acethylneuraminice 4-methylumbelliferyl ketoside 0.01M PBS (pH 5.9) 200 $\mu l$ を $37^{\circ} \mathrm{C}$ で 4 時間 incubation し, $10 \% \quad \mathrm{Na}_{2} \mathrm{CO}_{3}$ $3,000 \mu l$ 添加し, 反応停止後 Ex $327 \mathrm{~nm}, \operatorname{Em} 448 \mathrm{~nm}$ で 螢光強度を湘定し, 標準物質より neuraminidase 活性 を求めた。

(ii) 血中遊離シアル酸の測定 ${ }^{5)}$ ：螢光法を用いた。 クエ ン酸加血漿 $50 \mu l$ と $0.1 \mathrm{~N} \mathrm{H}_{2} \mathrm{SO}_{5} 1,000 \mu l, \quad 0.025 \mathrm{M}$ periode acid $250 \mu l$ を加光, $37^{\circ} \mathrm{C}, 30$ 分 incubation ᄂ, $2 \%$ sodium arsenite $200 \mu \mathrm{l}, 1.62 \%$ thiobarbituric acid $2,000 \mu l$ 添加し, 7.5 分間水浴中で boiling し, 冷水で冷却後, $5 \%$ HCl-butanol $3,000 \mu l$ で反応生成物 を混和し，遠心 (3,000 rpm, 10分)を行い butanol 層に 抽出する。この抽出液を Ex 550nm, Em 570nm で螢光 強度を測定し, 標準物質より濃度を求めた。

(iii)血中ムユ蛋白の測定 ${ }^{6)}$ : ASPRO-GP 法 (大塚アッ セイ研究所）を用いた。被検血漿 $100 \mu l$ を除蛋白液 (0.6M 過塩素酸) で除蛋白 (3,000 rpm, 20分) し, 除 蛋白上清 $200 \mu l$ と呈色試薬を反応させ，15分放置後， $590 \mathrm{~nm}$ の吸光度を測定し, 標準物質より濃度を求めた.

(iv)ィブリノーゲン測定：トロンビン凝固時間法

(v)白血球・血小板数：自動血球計数機 (Model CC 720，PL-100 東亜医用電子）を用いた。

\section{成 績}

(1) one shot 注入法

注入量は $0.5 \mathrm{u} / \mathrm{kg}$ が限度であり, 一度に多量の注入 の場合, 血小板の急減あるいは血管内溶血を伴って出血 死する例が多くみられた。一方 $0.2 \mathrm{u} / \mathrm{kg}$ の少量では一 
